\title{
SINERGIAS NAS FUSÕES E AQUISIÇÕES DO SETOR DE EDUCAÇÃO SUPERIOR NO BRASIL
}

\author{
Synergies in Mergers and Acquisitions in the Higher Education Sector in Brazil
}

Recebido em 24.09.2013. Aprovado em 13.11.2013

Avaliado pelo sistema double blind review

DOI: http://dx.doi.org/10.12712/rpca.v7i4.317

\section{Gilberto Sarfati}

gilberto.sarfati@fgv.br

Fundação Getúlio Vargas - Escola de Administração de Empresas de São Paulo FGV-EAESP - São Paulo - SPBrasil.

\section{Alan Shwartzbaum}

alands@gmail.com

Fundação Getúlio Vargas - Escola de Administração de Empresas de São Paulo FGV-EAESP - São Paulo - SPBrasil.

\section{Resumo}

O presente trabalho objetiva entender por que as empresas do setor de educação tem adotada a estratégia de aquisições e fusões, ao invés de simplesmente se basearem no crescimento orgânico. A hipótese é que existem sinergias nas transações realizadas no setor de educação superior no Brasil, bem como que estas sinergias têm sido convertidas em ganhos econômicos para as empresas adquirentes e para os seus acionistas. Para tanto, o presente trabalho primeiramente apresenta uma revisão da literatura do tema de fusões e aquisição e também uma visão sobre o setor brasileiro de educação superior, incluindo sua evolução, regulamentação e outras informações relevantes para apoiar um entendimento mais profundo sobre o fenômeno estudado. Em seguida, baseando-se na metodologia proposta, o trabalho foca no teste de sua hipótese, através da identificação das sinergias específicas presentes no setor e nas empresas selecionadas (Anhanguera, Estácio e Kroton) e da análise de como estas sinergias estão sendo traduzidas em seus resultados econômicos. Finalmente, com base nas evidências geradas por tais discussões, são providas conclusões relativas à veracidade da hipótese.

Palavras-chave: Fusões e aquisições. Estratégia de crescimento aquisitivo. Sinergias. Rentabilidade. Educação superior

\begin{abstract}
The present work aims to understand why companies in the sector of education has adopted a strategy of acquisitions and mergers, rather than simply relying on organic growth. The hypothesis is that there are synergies in transactions in the higher education sector in Brazil, as well as these synergies have been converted into economic gains for the acquiring companies and their shareholders. Therefore, this paper first presents a literature review of the topic of mergers and acquisition and also an insight into the Brazilian higher education, including its evolution, regulation and other relevant information to support a deeper understanding of the phenomenon studied. Then, based on the proposed methodology, the work focuses on testing their hypothesis by identifying the specific synergies through the industry and the companies selected (Anhanguera, Estacio and Kroton) and analyzing how these synergies are being translated into its economic results. Finally, based on the evidence generated by such discussions, conclusions are provided regarding the veracity of the hypothesis.
\end{abstract}

Keywords: Mergers and acquisitions. Acquisitive growth strategy. Synergies. Profitability. Higher education. 


\section{SINERGIAS NAS FUSÕES E AQUISIÇÕES DO SETOR DE EDUCAÇÃO SUPERIOR NO BRASIL}

\section{Introdução}

No primeiro semestre de 2012, foram realizadas no Brasil 433 transações relevantes de fusões e aquisições, segundo mapeamento da KPMG (2012). Isso representa mais de três transações por dia útil, em média. Estas transações movimentam bilhões de reais anualmente no Brasil, e múltiplas vezes mais ao redor do mundo, tanto em mercados desenvolvidos, quanto em emergentes. 0 presente trabalho se propõe a analisar as fusões e aquisições em um setor no qual este fenômeno tem estado em grande evidência nos últimos cinco anos: a educação superior privada no Brasil. Este setor chama a atenção não apenas pela frequência de transações, mas também pelo porte de algumas delas, fazendo com que a adoção da estratégia de crescimento aquisitivo elevasse empresas brasileiras ao conjunto das maiores instituições de educação superior do mundo em número de alunos.

A questão de pesquisa é por que fusões e aquisições têm sido um dos principais pilares das estratégias de crescimento dos grandes grupos privados de educação superior no Brasil? Diferentemente de diversos artigos da área que buscam apenas verificar se as transações impactam o preço das ações das empresas envolvidas, o presente trabalho passa a focar numa discussão fundamentada de quais são as motivações para a ocorrência destes processos, tanto as de caráter econômico, como as de caráter não-econômico. Ou seja, a hipótese é que existem sinergias a serem geradas através das fusões e aquisições bem como que estas sinergias têm se transformado em ganhos econômicos para os acionistas das empresas adquirentes.

0 presente trabalho se propõe a buscar evidências favoráveis a essa hipótese, analisando mais especificamente, as três empresas do setor que se destacaram por suas estratégias de crescimento aquisitivo nos últimos anos: Anhanguera Educacional (Anhanguera), Estácio Participações (Estácio) e Kroton Educacional (Kroton).

Com esta finalidade, divide-se a busca por evidências favoráveis à hipótese levantada em duas etapas. A primeira é identificar as sinergias que existiriam nas transações do setor. A segunda é a de analisar se tais sinergias têm, de fato, se traduzido em ganhos econômicos.

Para testar a primeira parte da hipótese, o trabalho se debruça na identificação de quais seriam as potenciais sinergias específicas do setor, discutindo quatro principais efeitos: (i) aumento de receitas, (ii) redução de custos e despesas, (iii) benefícios fiscais e (iv) redução dos custos de capital. Isso foi feito a partir de um detalhado debate sobre cada um dos fatores que impactam materialmente os resultados econômicos das empresas estudadas, especialmente a sua rentabilidade. Além da identificação teórica das potenciais sinergias, sustentada pela compreensão mais detalhada dos principais direcionadores de valor das empresas do setor, contou-se também com uma perspectiva das próprias empresas sobre o assunto.

Feita a identificação, o trabalho finalmente se volta para a sua etapa final, que é a verificação se as sinergias cujos impactos foram considerados relevantes estariam realmente influenciando positivamente os resultados das empresas e, consequentemente, a geração de valor ao acionista, o pilar de toda e qualquer motivação de natureza econômica para as empresas.

\section{Fusões e aquisições}

Uma relevante parcela dos estudos de administração de empresas se baseia na premissa que o objetivo das empresas, ao menos as privadas com fins lucrativos, é a maximização do valor gerado aos seus acionistas, como defendem Brigham e Ehrhardt (2005). Sob a perspectiva com grande enfoque financeiro destes autores, a maximização do valor se traduz, em última 
instância, nos dividendos gerados aos acionistas e na valorização de suas ações.

Kluyver e Pearce II (2007), ao concordarem que as empresas devem criar valor aos seus acionistas, defendem que as estratégias empresariais devem se concentrar neste objetivo. Dentro dos elementos destas estratégias, os autores ressaltam a importância do crescimento da empresa como um dos direcionadores desta criação de valor, ao destacarem que economias de escala e de escopo são importantes fontes de aumento de rentabilidade, que, portanto, tendem a se traduzir em maior geração de caixa.

Pindyck e Rubinfeld (2005) explicam que economias de escala ocorrem quando a empresa é capaz de aumentar sua produção desproporcionalmente acima do aumento de seus custos. Economias de escopo, por outro lado, existiriam quando a produção conjunta de uma única empresa (ou ativo) seria maior que o de mais empresas (ou ativos) separadamente com equivalentes custos, ou, logo, para um mesmo nível de produção, o custo de se produzir numa única empresa (ou ativo) seria menor.

Segundo ainda Kluyver e Pearce II (2007), há três formas de uma empresa crescer, as quais os autores chamam de "paradigma build, buy or bond - construir, comprar ou coligar" (KLUYVER; PEARCE II, 2007, p. 159). Build, ou construir, se refere ao crescimento orgânico ou interno da empresa. Por sua vez, buy, ou comprar, se refere ao crescimento por meio de aquisição. E, finalmente, bond, ou coligar, se refere ao crescimento por meio de alianças.

Berkovitch e Narayanan (1993) apresentam as possíveis motivações para fusões e aquisições em três categorias: sinergia, agência e arrogância. 0 conceito de sinergia na visão dos autores implica em ganhos econômicos provenientes da fusão dos recursos das empresas envolvidas na transação. 0 conceito de agência, por sua vez, está alinhado com a perspectiva gerencial, em que o bem-estar do acionista pode ser reduzido em detrimento do bem-estar dos administradores. Finalmente, a terceira categoria, arrogância se refere a possíveis erros de avaliação feitos pelos administradores ao optarem por uma aquisição, pagando mais por ela do que o valor que ela seria capaz de adicionar.

Kode, Ford e Sutherland (2003) afirmam que a maioria das transações de fusões e aquisições é justificada pela existência de sinergias, sendo poucos os casos motivados por outras razões, empiricamente. Os autores também explicam que o valor criado por estas sinergias representam o teto do prêmio que pode ser pago pela empresa adquirida, isto é, a diferença entre o valor efetivamente pago na transação e o desta empresa-alvo no chamado cenário stand-alone (cenário em que a empresa-alvo continuaria suas operações de forma totalmente independente, como se a transação não ocorresse). Os autores ainda acrescentam que quase todas as transações de fusões e aquisições que são julgadas como fracassadas após a sua concretização são aquelas que falham em entregar um valor de sinergias superior ao prêmio desembolsado aos vendedores da empresa adquirida, muitas' vezes por equívocos na avaliação do potencial destas sinergias. Portanto, a compreensão profunda das sinergias é essencial para sustentar o próprio racional da estratégia de crescimento por fusões e aquisições.

Para tanto, Chatterjee (1986) classifica as sinergias da esfera organizacional em três diferentes tipos: sinergias de conluio, sinergias operacionais e sinergias financeiras. As sinergias de conluio são as relacionadas a preço, que o autor explica como as aquelas que provêm da habilidade de aumento de preço dos produtos e serviços pelo efeito de concentração gerado pela fusão ou aquisição, similar ao aumento de poder de mercado proveniente de um conluio. Já as sinergias operacionais são as decorrentes da possibilidade da empresa combinada produzir a custos mais baixos, pelos efeitos das economias de escala e de escopo. As sinergias financeiras, por sua vez, são principalmente procedentes da possibilidade de diminuição do risco do negócio combinado como efeito da diversificação e da consequente redução do custo de capital pela lógica da 


\section{SINERGIAS NAS FUSÕES E AQUISIÇÕES DO SETOR DE EDUCAÇÃO SUPERIOR NO BRASIL}

relação entre risco e retorno, tratada por Brigham e Ehrhardt (2005).

Em seu estudo, Chatterjee (1986) ressaltou as sinergias de conluio, argumentando que estas são, na média, as capazes de agregar maior valor, com base em suas pesquisas. É válido, todavia, destacar que as sinergias de conluio somente podem ocorrer em um contexto particular. Primeiramente, pelo fato de ser resultante do aumento de poder de mercado, ela não poderia ocorrer em qualquer estrutura de mercado, que são quatro, conforme Pindyck e Rubinfeld (2005): monopólio, oligopólio, concorrência monopólica e concorrência perfeita. No caso da existência de um monopólio, as próprias fusões e aquisições horizontais, geradoras da sinergia de conluio, não teriam aplicabilidade. Já na estrutura de concorrência perfeita, em teoria, nenhuma empresa teria a capacidade de exercer influência sobre os preços. Restariam, portanto, oligopólios e concorrências monopólicas, estruturas em que as sinergias de conluio passariam a fazer sentido. Porém, justamente por isso, a regulamentação antitruste atua para limitar os retornos excessivos das empresas com significativo poder de mercado, atuando como um desincentivo às fusões e aquisições motivadas pelas sinergias de conluio.

As sinergias financeiras, por outro lado, por serem frutos da diversificação, como também explicam Weston, Chung e Hoag (1990), tenderiam a acontecer em qualquer transação de fusões e aquisições, uma vez que existiria sempre algum grau de diversificação, já que, como elucidam Brigham e Ehrhardt (2005), é altamente improvável em termos reais a existência de correlação positiva perfeita dos retornos isolados da adquirente e da adquirida, fazendo com que o risco dos ativos combinados seja menor que dos ativos individuais. Ainda segundo Brigham e Ehrhardt (2005), devido à relação intrínseca entre risco e retorno, o custo de capital decresce à medida que a diversificação elimina riscos isolados parcialmente.

Em contrapartida, Chatterjee (1986) faz uma consideração em relação ao impacto das sinergias financeiras, ao debater sobre a questão do porte das empresas envolvidas na transação. De fato, caso o tamanho da empresa adquirente seja significativamente maior que o da empresa adquirida, o efeito de redução do custo de capital pela diversificação deve ser pequeno. Quanto maior esta diferença de porte, maior a tendência de que a sinergia financeira seja insignificante.

Por outro lado, Meeks (1977), ao discutir a questão do financiamento de fusões e aquisições, explica que uma parcela considerável de transações de fusões e aquisições é financiada com capital de terceiros, o que não ocorre na mesma proporção no caso de opção por crescimento orgânico. Levando em conta que, segundo esclarecem Brigham e Ehrhardt (2005), o custo de capital de terceiros em termos marginais é inferior ao custo do capital próprio, a aquisição financiada com recursos de terceiros impactaria na estrutura de capital e, consequentemente, no custo médio ponderado do capital.

Previamente ao início das discussões sobre as sinergias operacionais, é necessário separar o caráter operacional do de conluio nas sinergias resultantes de aumento de receitas. 0 aumento de receitas, como explicam Martelanc, Pasin e Pereira (2010), só pode ser compreendido como gerador de sinergias caso a receita potencial da empresa combinada seja, de alguma forma, superior à soma da receita da adquirente e da adquirida separadamente. Isto é, é extremamente provável que a receita da empresa resultante seja maior logo de início, devido à mera soma das partes, mas a soma de receitas somente terá algum potencial sinérgico caso haja algum elemento que as potencialize por estarem combinadas.

A primeira possibilidade apontada por Martelanc, Pasin e Pereira (2010) de isto ocorrer está relacionada com o aumento de poder de mercado, o que é claramente a sinergia de conluio anteriormente apontada. Porém, quebrando-se a receita nos seus dois componentes que se 
multiplicam, quantidade de produtos ou serviços e preço unitário, é possível identificar com maior clareza como as fusões e aquisições podem gerar um aumento de receitas sinérgico do ponto de vista operacional.

Já as sinergias de redução de custos e despesas podem ser decorrentes de quatro principais fatores, de acordo com Matias e Pasin (2001) e Martelanc, Pasin e Pereira (2010): economias de escala, economias de integração vertical, utilização de recursos complementares e transferência de tecnologia entre as empresas.

Quando se tratam dos benefícios fiscais, Devos, Kadapakkam e Krishnamurthy (2009) explicam que relevantes sinergias podem ser criadas a partir da redução dos tributos pagos pelas empresas a partir de vantagens criadas a partir da combinação das empresas. Hayn (1989) aponta três principais fontes de sinergias tributárias: utilização de prejuízos fiscais acumulados de uma empresa na outra, aproveitamento de créditos fiscais não utilizados de uma empresa na outra e possibilidade de se aplicar alguma taxa de depreciação contábil mais acelerada, o que reduz a base de cálculo dos tributos que incidem sobre o lucro.

Apesar da existência de diversas fontes de ganhos sinérgicos, todas elas relevantes, é válido sublinhar que nem sempre elas são aplicáveis a toda e qualquer transação. A sua aplicabilidade depende não apenas do tipo de transação (horizontal, vertical e de conglomerado), mas também de questões mais específicas, como a natureza e a estrutura do setor e da indústria no qual ela ocorre, assim como características do mercado geográfico, inclusive de seus pontos regulatórios, como, por exemplo, a regulamentação antitruste e as leis e normas que regem as questões tributárias. De acordo com o complexo arranjo deste grande número de variáveis, o potencial de sinergias pode variar muito, podendo ser inexistente, ou até mesmo negativo, como explanam Matias e Pasin (2001) e Wood Jr., Vasconcelos e Caldas (2004).

\section{Evolução do setor de educação superior privada no Brasil}

A educação privada, isto é, a possibilidade de exploração da educação como um negócio é, por si só, um tema bastante polêmico no mundo acadêmico. Como explicam Amaral e Magalhães (2000), a educação é tema de interesse que uma grande quantidade e diversidade de stakeholders, dentre os quais podem se destacar os alunos, a sociedade civil, o estado, os professores, os gestores e os demais funcionários ou empregados das instituições de ensino. No caso da educação privada, adiciona-se o mercado, na figura dos investidores privados, à lista de partes interessadas.

Em 2010, segundo o Instituto Nacional de Estudos e Pesquisas Educacionais (INEP) (2012), havia registradas 2.100 instituições deste tipo no Brasil, aproximadamente $74 \%$ a mais do que o número observado no início da década, de 1.208 em 2001. As instituições públicas, por outro lado, somavam apenas 278 em 2010, menos de 12\% do número total de instituições de ensino superior no país.

Outro fenômeno observado foi que a participação da iniciativa privada na oferta de vagas educação superior no Brasil, que já vinha aumentando desde as mudanças regulatórias da década de 1970, apresentou uma franca e contínua expansão desde a Lei de Diretrizes e Bases de 1996. Conforme o INEP (2012), no ano de 2010 as instituições de ensino superior privadas correspondiam a aproximadamente três quartos do total de matrículas realizadas no país. No período entre 1995 e 2010, a taxa média de crescimento no número de matrículas em estabelecimentos privados foi de expressivos 10,5\% ao ano, consideravelmente superior à taxa de 5,8\% ao ano apresentada pelos estabelecimentos públicos.

Adicionalmente, outra importante mudança estrutural no ensino superior brasileiro é o surgimento da modalidade de ensino à distância, com o advento das tecnologias que permitiram a sua disseminação em larga escala. Otranto (2006) ressalta que, na visão do governo federal, a 


\section{SINERGIAS NAS FUSÕES E AQUISIÇÕES DO SETOR DE EDUCAÇÃO SUPERIOR NO BRASIL}

consolidação do modelo de ensino à distância seria essencial para o aumento maciço do número de vagas no curto e no médio prazo, uma vez que mesmo com a ampliação dos montantes de recursos destinados à educação superior, não seria possível crescer de maneira consistente e rápida com a oferta de vagas no ensino presencial. De fato, em 2010 o ensino à distância foi responsável por quase um milhão de matrículas, frente a pouco mais de cinco mil no início da década.

Como ressalta o IBGE (2012), o impacto direto destas taxas diferenciadas de crescimento de renda é a diminuição da desigualdade social, medida através do índice de Gini, que caiu de 0,518 em 2009 para 0,501 em 2011. Do ponto de vista das instituições de ensino superior privadas, este crescimento acelerado da renda das classes sociais com rendimento mais baixo pode ser entendido como um importante fator de expansão da demanda, uma vez que estas camadas estiveram tradicionalmente privadas do acesso ao ensino superior.

De acordo com Sécca e Leal (2009), uma parcela expressiva do crescimento acelerado do ensino superior privado no Brasil também tem se devido a incentivos do governo federal. Dentre os incentivos, podem-se destacar, segundo os autores, dois programas principais: o Programa Universidade para Todos (Prouni) e o Financiamento Estudantil (FIES).

Sécca e Leal (2009) esclarecem que o Prouni é um programa criado em 2004 pelo governo federal, através do Ministério da Educação, cujo objetivo é a concessão de bolsas de estudo, integrais ou parciais, para alunos de baixa renda ou provenientes de instituições públicas de ensino fundamental cursarem o ensino superior em instituições de ensino privadas, dada a deficitária oferta de vagas nos estabelecimentos públicos.

Inicialmente, como explica Cieglinski (2011), a contrapartida da isenção fiscal dada às instituições de ensino superior privadas era a oferta total de vagas ao programa, com base no escalonamento proposto na lei. Contudo, após o questionamento deste mecanismo pelo Tribunal de Contas da União, uma vez que uma parte das vagas ofertadas permanecia ociosa, a legislação foi alterada em 2011, de forma a vincular a concessão do incentivo fiscal ao preenchimento de vagas do Prouni, não apenas à oferta.

Ainda assim, o Prouni é um programa que gera uma demanda expressiva de vagas no ensino superior privado. De acordo com o Sistema Prouni (2012), já foram oferecidas mais de 1,6 milhão de vagas em estabelecimentos privados para alunos habilitados a participar do programa desde 2005. Na perspectiva desses estabelecimentos, segundo Carvalho (2006), o Prouni é bastante benéfico, não apenas porque gera significativas economias na carga tributárias, mas também porque permite a ocupação de vagas ociosas com uma demanda que não existiria na ausência do programa.

O Financiamento Estudantil (FIES), o outro programa federal que ajudou a alavancar o crescimento da educação superior privada no Brasil nos últimos anos, conforme Sécca e Leal (2009), criado através da Caixa Econômica Federal em 1999. Segundo a Caixa Econômica Federal (2012), este programa objetiva o financiamento, com custo e condições atrativos, do ensino superior a alunos matriculados em instituições privadas cadastradas no programa e bem avaliadas pelos critérios do Ministério da Educação e que não apresentem condições financeiras suficientes para o pagamento de seus cursos, incluindo aqueles que tenham recebido bolsas parciais do Prouni. De acordo com a própria Caixa Econômica Federal (2012), mais de 560 mil alunos já foram beneficiados pelo programa, com mais de $\mathrm{R} \$ 6$ bilhões já aplicados.

Apesar da grande receptividade destes programas por parte dos alunos e das empresas de 
educação, autoras como Carvalho (2006) e Otranto (2006), são bastante críticas aos subsídios dados pela esfera pública à privada na educação superior, especialmente no tocante da qualidade do ensino provido nos estabelecimentos privados, o que parece ser cabível, mas desprezando a capacidade de oferta e de gestão que a iniciativa pública teria para um número compatível de vagas criadas pela iniciativa.

O que a OECD (2012) revela é que, na verdade, os subsídios do governo brasileiro ao setor de educação superior privado ainda são pouco representativos em termos comparativos. Com base em dados de 2008, a OECD (2012) mostra que estes subsídios representaram somente 9,5\% dos gastos públicos com educação, frente à média de 21,0\% observada nos países da OECD. Em países como o Chile e o Reino Unido, este percentual chega a 55,6\% e 53,3\%, respectivamente. Em termos de percentual o produto interno bruto (PIB), o Brasil gastou apenas 0,08\% em subsídios à educação superior privada, enquanto a média dos países da OECD foi de 0,28\%, 3,5 vezes superior.

Ainda que todos estes números relativos à educação superior no Brasil apontem ao forte crescimento verificado nos últimos anos, é válido destacar que ainda há um espaço muito grande para o crescimento deste setor. Segundo o INEP (2012), a taxa de escolarização líquida no Brasil em 2009 foi de 14,4\%, ou seja, apenas um a cada sete habitantes com idade adequada para o nível superior está de fato matriculado, um nível baixo comparado não apenas a países desenvolvidos, mas também muitos a outros países emergentes. Um estudo realizado pela Organização para a Cooperação e Desenvolvimento Econômico, OECD (2011), mostra que, em 2009, apenas $11,6 \%$ da população brasileira entre 25 e 34 anos de idade tinha concluído o ensino superior. Este nível é inferior a todos os países da OECD. Incluindo os países do G20 que não fazem parte da OECD e que possuem estatísticas disponíveis, o Brasil só está acima da China neste critério.

Assim, como resultado do acelerado crescimento observado nos últimos anos e do ainda muito expressivo potencial de crescimento para o futuro, uma consequência tem sido não apenas o crescimento do setor de educação superior privado em número de instituições, conforme mostrado pelo INEP (2012), já mencionado, mas também um processo consolidador, com o fortalecimento de algumas empresas de educação através de sucessivas transações de fusões e aquisições, o terceiro fato abordado por este trabalho, como explicado anteriormente.

Um estudo realizado pela KPMG (2012) aponta o significativo número de transações que tem ocorrido especificamente no setor de educação nos últimos anos. Até 2007, este setor era incluído nos estudos desta consultoria na categoria 'outros', mas devido ao grande número de transações que aconteceram a partir de 2008, a categoria 'educação' passou a ser analisada de forma isolada.

Naquele ano, foram mapeadas 53 transações relevantes pela KPMG (2012), que corresponderam a 8\% do total de transações mapeadas. Em 2009, houve uma queda neste número, podendo ser resultado dos efeitos da crise financeira observados naquele ano, com retração generalizada do investimento dos setores privados, quando foram detectadas apenas 12 transações. Em 2010, 20 transações foram mapeadas e, em 2011, 27. Finalmente, apenas no primeiro semestre de 2012, foram identificadas oito transações. 0 número, apesar de menor que o observado em anos anteriores, não revela o montante médio transacionado neste ano, que foi bastante superior.

\section{Metodologia}

A pergunta de pesquisa é porque fusões e aquisições têm sido um dos principais pilares das estratégias de crescimento dos grandes grupos privados de educação superior no Brasil? Com base na literatura acadêmica que aborda o tema de fusões e aquisições, apresentada 


\section{SINERGIAS NAS FUSÕES E AQUISIÇÕES DO SETOR DE EDUCAÇÃO SUPERIOR NO BRASIL}

anteriormente, as motivações para a escolha desta estratégia podem seguir duas lógicas: a de maximização do valor ao acionista, uma lógica econômica, e a de maximização da utilidade dos executivos, uma lógica gerencial.

A hipótese levantada é que existem sinergias a serem geradas através das fusões e aquisições no setor de educação superior privado, bem como que estas sinergias têm se transformado em ganhos econômicos para os acionistas das empresas adquirentes.

A metodologia desta pesquisa é composta de duas etapas, a fim de testar os dois componentes presentes na hipótese levantada, (i) a existência de sinergias nas fusões e aquisições do setor de educação superior privado e (ii) a tradução destas eventuais sinergias em valor ao acionista, separadamente.

Dentre os grupos educacionais brasileiros destacam-se as três maiores em números de alunos: Anhanguera, Estácio e Kroton. Juntas, de acordo com os relatórios do terceiro trimestre de 2012 da Anhanguera (2012a), Estácio (2012b) e Kroton (2012a), estas três empresas possuem aproximadamente 1,1 milhão de alunos, ou seja, algo estimado em mais de $20 \%$ do total de alunos matriculados no ensino superior privado no Brasil em 2012.

Estas três empresas foram selecionadas para serem estudadas pelo presente trabalho, pois, além do porte expressivo, estas empresas também compartilham da estratégia de crescimento através de fusões e aquisições horizontais, alavancadas todas as três por investidores financeiros (fundos de private equity). Não menos importante também é o fato de se tratarem de empresas de capital aberto e que, portanto, possuem uma quantidade significativa de informações públicas disponíveis, que permitem a realização das análises propostas pela metodologia deste trabalho.

Primeiramente, para identificar se de fato existem sinergias nas fusões e aquisições no setor de educação superior, fez-se necessário tentar entender como os quatro tipos de sinergias apontados por Martelanc, Pasin e Pereira (2010) (aumento de receitas, redução de custos e despesas, benefícios fiscais e redução dos custos de capital) se aplicariam especificamente ao setor. Para tanto, foram analisadas as diferentes linhas dos demonstrativos financeiros das empresas de educação superior de capital aberto, a fim de se compreender quais eram os direcionadores de valor mais relevantes da indústria. Para complementar a análise na questão dos custos, demonstrados de maneira agregada nos demonstrativos de resultados, foram utilizados documentos que revelaram os principais componentes da estrutura de custos e despesas destas empresas: (i) a apresentação de resultados do segundo trimestre de 2012 da Estácio (2012a), (ii) um laudo de avaliação da Estácio preparado pela Apsis (2011), disponível publicamente e (iii) o prospecto definitivo de distribuição de units (Certificados de depósitos de ações, compostos, no caso da Anhanguera, por uma ação ordinária e seis ações preferenciais ) da Anhanguera (2007).

Com base na melhor compreensão dos direcionadores de valor do setor, preparou-se um questionário que traduzisse todas as principais potenciais sinergias específicas, dos quatro diferentes tipos, a serem enviados e respondidos pelas três empresas selecionadas que são estudadas no presente trabalho: Anhanguera, Estácio e Kroton. 0 questionário foi enviado às áreas indicadas pela área responsável por relações com investidores de cada empresa em agosto de 2012. 0 objetivo do questionário foi o de obter, da perspectiva das próprias empresas, quais das potenciais sinergias identificadas de fato ocorrem e quais as mais relevantes.

Para testar o segundo componente da hipótese, ou seja, a tradução das eventuais sinergias em 
valor ao acionista, a metodologia proposta se baseia nos trabalhos de Matias e Pasin (2001) e de Carmargos e Barbosa (2005). Estes autores propõem, essencialmente, que a verificação se uma transação foi bem sucedida do ponto de vista de geração de valor ao acionista da empresa adquirente, isto é, se de fato gerou sinergias, seja feita através da análise de indicadores do desempenho econômico-financeiro das empresas selecionadas. De acordo com Matias e Pasin (2001), bem como Meeks (1977), indicadores de rentabilidade são métricas apropriadas para a análise de sinergias, o que é corroborado pelos quatro tipos de sinergias apresentados por Martelanc, Pasin e Pereira (2010), já que todos os tipos se convertem, de algum modo, numa mudança positiva no nível de rentabilidade.

Observando os demonstrativos financeiros das empresas selecionadas, é possível construir e analisar índices capazes de indicar melhorias que podem ser decorrentes das sinergias das sucessivas transações de fusões e aquisições nas quais estas empresas estiveram envolvidas. Todavia, nem todos os tipos de sinergia podem ser capturados pela análise dos indicadores financeiros. A título de exemplo da aplicação da metodologia de análise de indicadores econômico-financeiros, Matias e Pasin (2001) utilizaram três principais indicadores para analisar os efeitos sinérgicos de fusões e aquisições numa amostra de 22 transações que ocorreram no Brasil entre 1995 e 1997: (i) evolução percentual do custo dos produtos vendidos sobre as receitas líquidas, (ii) evolução percentual das despesas administrativas e gerais sobre as receitas líquidas e (iii) evolução do índice de rentabilidade do patrimônio líquido (ou retorno sobre o patrimônio líquido).

A análise destes e de outros indicadores financeiros, ainda que também possam ser influenciados por variáveis externas, proporciona indícios concretos de captura de sinergias quando observados em sua evolução, isto é, comparando-se os níveis anteriores da adoção mais consistente da estratégia de crescimento por fusões e aquisições aos níveis mais atuais. Este é o tipo de análise conduzida no capítulo que busca verificar se as eventuais sinergias das fusões e aquisições promovidas pelas empresas de educação superior têm se transformado em criação de valor aos seus acionistas.

\section{Sinergias identificadas}

Focando na classificação de Martelanc, Pasin e Pereira (2010), a primeira fonte de ganho sinérgico para as empresas de caráter operacional seria o aumento desproporcional de receitas. Qualquer aquisição pode simplesmente elevar a receita da adquirente pela soma de suas receitas recorrentes à base da adquirente, o que não constitui um ganho sinérgico. Todavia, mudanças positivas na tendência de crescimento destas receitas, ora da adquirida, ora da adquirente, ora das duas, constituiriam sinergias operacionais.

Do lado da quantidade, a suposição levantada foi que a integração das instituições adquiridas poderia lhes conferir maior atratividade de alunos, devido à aplicação de diferenciais competitivos das adquirentes, como sistema de ensino, estrutura tecnológica, condições comerciais e, principalmente, marca. Segundo Domingues, entrevistado da área de Fusões e Aquisições da Diretoria de Finanças e Relações com Investidores da Estácio, esta sinergia de fato existe. Ele explica que, no caso da Estácio, a capacidade de atração de alunos da instituição adquirida é potencializada pela capacidade da empresa de investir nas questões relacionadas a marketing e vendas, tecnologia de ensino e, também, em novos cursos, que podem requerer investimentos mais significativos, como laboratórios, por exemplo. Desta forma, ainda que no momento da aquisição o número total de alunos seja a simples soma das partes, a aplicação dos recursos e das competências da instituição adquirente na adquirida tende a acelerar a taxa de crescimento da base de alunos e até mesmo atrair alunos que outrora não se interessariam pela instituição adquirida, seja por uma questão de oferta de cursos, credibilidade da marca, 


\section{SINERGIAS NAS FUSÕES E AQUISIÇÕES DO SETOR DE EDUCAÇÃO SUPERIOR NO BRASIL}

estrutura física e/ou condições comerciais, entre outros.

No tocante ao preço, a suposição levantada foi que a integração da instituição adquirida no grupo adquirente poderia levar a uma convergência do valor médio da mensalidade da adquirida, caso mais baixo, ao valor médio praticado pela adquirente em condições similares. Isto poderia ser justificado também pela aplicação de atributos capazes de influenciar a percepção de valor por parte do consumidor, da adquirente na adquirida, como explicado no item anterior (o efeito da marca, melhores instalações, cursos diferenciados etc.). Novamente, esta suposição foi confirmada por Domingues, que explica que, apesar de haver variações nas mensalidades em função da região geográfica e dos cursos oferecidos, há uma tendência que as instituições adquiridas adéquem suas mensalidades à média do grupo, à medida que o modelo do grupo vai sendo implementado.

Para a discussão da segunda fonte de sinergias das fusões e aquisições na classificação abordada, a redução de custos e despesas, fez-se necessário entender quais são os principais componentes das estruturas de custos das instituições de ensino superior privadas. Nos demonstrativos financeiros das empresas estudadas, a linha de custos totais sempre é mostrada de forma agrupada, isto é, sem uma abertura detalhada de quais os tipos de custos que a compõem. Outros documentos encontrados, todavia, desvendam tais componentes especificamente para as empresas estudadas. São eles (i) a apresentação de resultados do segundo trimestre de 2012 da Estácio (2012a), (ii) um laudo de avaliação da Estácio preparado pela Apsis (2011), disponível publicamente e (iii) o prospecto da abertura de capital da Anhanguera (2007).

De acordo com estes documentos, pode-se afirmar que os principais componentes da estrutura de custos das empresas de educação superior são: (i) custos de pessoal (corpo docente, apoio docente, encargos sociais e benefícios), (ii) aluguel, condomínio e imposto predial e territorial urbano (IPTU), (iii) material didático e (iv) manutenção, segurança, limpeza e utilidades, além da (v) depreciação, que não é um custo que impacta o caixa.

Segundo a Estácio (2012a), os custos de pessoal, já incluindo os encargos sociais, representaram no segundo trimestre de 2012 cerca de $47 \%$ da receita líquida e $75 \%$ do total do 'custo caixa', isto é, o total de custos dos serviços prestados excluindo-se depreciação e amortização. Em seguida, aluguel, condomínio e IPTU, representando aproximadamente $8 \%$ da receita líquida e $13 \%$ do custo total e material didático, 4\% e 6\%, respectivamente. Em relação à receita líquida, esse total de custos representou 63\% no período. Já a Apsis (2011) considerou em seu laudo de avaliação que os custos de pessoal representariam $46 \%$ da receita líquida (sendo $80 \%$ deles referentes ao corpo docente e $20 \%$ ao apoio docente), aluguel e custos relacionados seriam $9 \%$ da receita líquida, utilidades 3\%, e segurança e limpeza outros $2 \%$.

Em relação às despesas comerciais, a Estácio (2012a) demonstra que as despesas de provisão com devedores duvidosos representam cerca de $9 \%$ da receita líquida e o gasto publicitário 5\%. Já as despesas gerais e administrativas representam $12 \%$ da receita líquida, destacando-se o pessoal administrativo, correspondente a $6 \%$ da receita líquida, e serviços de terceiros, 3\% da mesma base. Enquanto isso, para a Apsis (2011) as despesas de provisão com devedores duvidosos quase $5 \%$ da receita líquida, as outras despesas comerciais também $5 \%$ e as despesas administrativas totais aproximadamente $13 \%$.

Seguindo a ordem dos custos mais relevantes, o mais representativo de todos é o custo do corpo docente. A princípio, sabe-se que a remuneração de um professor varia em função, especialmente, da sua carga horária de aulas lecionadas, a hora-aula. Desta forma, no ensino 
presencial, esse componente de custo tem natureza variável e, portanto, assumindo-se a premissa que o número de alunos por aula permanece inalterado no caso de uma aquisição, não haveria ganho sinérgico. Porém, é válido assumir que existe uma parcela da remuneração do corpo docente que é fixa, como, por exemplo, alguns benefícios. Também é necessário considerar outros custos relativos a este corpo docente que seriam fixos por colaborador, apesar de não se configurarem como remuneração, como é o caso do custo do recrutamento e seleção, programas de treinamento e desenvolvimento e tudo o que eventualmente tenha sido investido na formação deste profissional.

Logo, a possibilidade de se compartilhar um mesmo professor da instituição adquirente na adquirida, ou vice-versa, elevando a sua carga horária, tende a gerar uma diluição da parcela fixa do custo total. Portanto, se a empresa adquirente já possuir alguma instituição na mesma praça geográfica da adquirida, o compartilhamento do corpo docente poderia ser uma fonte de geração de sinergia. Na Estácio, por exemplo, o corpo docente pode sim ser compartilhado, dependendo da proximidade das unidades, no caso do ensino presencial. Já no caso do ensino à distância, em que o número de alunos por aula ministrada por um professor já é bem maior e tem flexibilidade maior para ampliação, este potencial ganho de escala proporcionado por uma aquisição gera uma clara diluição do custo do corpo docente e, consequentemente, verifica-se tal sinergia operacional.

No caso de outro custo relevante, o referente ao uso das instalações físicas no caso do ensino presencial, que inclui aluguel, condomínio e IPTU, se as instalações da instituição adquirida sejam mantidas, então não haveria potencial sinérgico específico. De forma análoga, os custos com utilidades (energia, água, telecomunicações etc.) também não tendem a apresentar potencial sinérgico.

Em relação ao material didático, é necessário dividir seu custo em dois componentes: o custo de elaboração e o custo de distribuição. Com base em informações mostradas nos sites das empresas estudadas, foi possível perceber que há o desenvolvimento de material didático, e até mesmo sistemas de ensino, por parte delas, que é aplicado de modo uniforme em praticamente todas as unidades. Logo, se o custo de elaboração é único, quanto mais alunos estiverem utilizando este material didático, mais diluído é o custo de elaboração, ou seja, menor o custo de elaboração por aluno.

Em relação ao custo de distribuição, caso o material seja impresso, então pode haver uma diluição em relação ao tamanho do lote de impressão, mas o principal custo, da matéria-prima, ainda seria variável. Porém, no caso de distribuição de material em formato eletrônico, cujo custo marginal tende à insignificância, também seriam observados relevantes ganhos de escala. Isto seria especialmente importante no caso da modalidade de ensino à distância.

Em relação às despesas comerciais, excetuando-se as despesas de provisão com devedores duvidosos que, como explicado anteriormente, tem uma natureza variável, se supôs que haveria potencial de sinergia nas aquisições do setor de educação superior. No que diz respeito ao gasto publicitário, as três instituições o focam principalmente em campanhas institucionais, não individualmente em cada unidade. Não apenas, todas as três comumente utilizam veículos de comunicação de massa e de abrangência nacional, logo, já atingindo consistentemente o público das praças onde viriam a realizar aquisições. Portanto, por estas duas características, uma vez que as instituições adquiridas passam pelo processo de integração e adotam a marca da adquirente, o que se tem observado nos casos das três empresas estudadas, um mesmo gasto publicitário beneficia um número maior de unidades e praças geográficas, proporcionando uma diluição.

Em relação ao custo do capital próprio, na perspectiva dos acionistas das empresas estudadas, 


\section{SINERGIAS NAS FUSÕES E AQUISIÇÕES DO SETOR DE EDUCAÇÃO SUPERIOR NO BRASIL}

caso as aquisições, ainda que horizontais, proporcionem algum tipo de diversificação, como nas questões de geografia ou de cursos oferecidos, poderia ocorrer, em tese, uma redução. Não apenas, caso o custo de capital próprio utilizado para avaliar as aquisições seja maior que o da empresa adquirente e que, feita a integração, o mercado não traduzisse essa diferença na percepção de risco da adquirente, o que é plausível, dado ao porte relativo das aquisições em comparação com o grupo como um todo, também poderia haver uma geração de valor.

Já em relação à estrutura de capital, se de fato as aquisições podem ser totalmente ou parcialmente financiadas com recursos de terceiros que não seriam aplicados no negócio caso não houvesse transação, então as aquisições podem levar a uma alteração na estrutura de capital da empresa adquirente, com uma elevação da proporção de recursos de terceiros que são mais baratos que os recursos próprios.

A tabela a seguir resume as principais sinergias identificadas especificamente para o setor estudado, com o entendimento sobre a sua probabilidade de impacto relevante nos resultados das empresas.

Tabela 1

Tipos de sinergias identificadas especificamente para o setor de educação superior privado brasileira

\begin{tabular}{|c|c|c|}
\hline Tipo de sinergia identificada & *Presente & **Impactante \\
\hline Aumento de receitas de natureza de conluio a nível nacional & Não & Não \\
\hline $\begin{array}{l}\text { Aumento de receitas de natureza de conluio a nível regional ou } \\
\text { local }\end{array}$ & Sim & Não \\
\hline Aumento de receitas de natureza operacional & Sim & Sim \\
\hline Redução dos custos do corpo docente e do apoio docente & Sim & Não \\
\hline Redução dos custos de aluguel, condomínio, IPTU & Não & Não \\
\hline Redução dos custos de utilidades & Não & Não \\
\hline $\begin{array}{l}\text { Redução dos custos de serviços terceirizados (manutenção, } \\
\text { segurança, limpeza etc.) }\end{array}$ & Sim & Sim \\
\hline Redução dos custos de material didático & Sim & Sim \\
\hline Redução das despesas com provisão de devedores duvidosos & Não & Não \\
\hline Redução das despesas comerciais e publicitárias & Sim & Sim \\
\hline Redução das despesas gerais e administrativas & Sim & Sim \\
\hline Redução de tributos (benefícios fiscais) & Não & Não \\
\hline Redução do custo de capital & Sim & Não \\
\hline
\end{tabular}

Fonte: autoria própria. 
* Entende-se como ausente as sinergias que, ainda que possam existir em casos excepcionais, não ocorrem usualmente no setor estudado.

** Entende-se como impactantes as sinergias que, além de presentes, são aquelas cujo impacto econômico esperado é maior e que, portanto, seriam os principais fatores motivadores das transações sob o ponto de vista econômico.

\section{Análise dos indicadores econômico-financeiros}

Para a análise das sinergias operacionais, os indicadores econômico-financeiros escolhidos para a análise foram: (i) taxa de crescimento da receita líquida, (ii) percentual de despesas comerciais, gerais e administrativas sobre a receita líquida, (iii) margem operacional e (iv) retorno sobre o patrimônio líquido. Para dar melhor embasamento às análises, optou-se por acompanhar a evolução trimestral dos indicadores, uma vez que a evolução anual proporcionaria uma amostra de observações pequena. Os números apresentados se referem ao total dos 12 meses anteriores ao fechamento de cada trimestre, a fim de também se amenizar variações relativas à sazonalidade.

\section{Taxa de crescimento da receita líquida}

Começando pelo aumento de receitas, não é possível através da análise dos indicadores segregar o componente sinérgico do não-sinérgico. Desta forma, o primeiro indicador, o crescimento da receita líquida, é analisada mais para ilustrar como as fusões e aquisições colocaram as empresas estudadas em patamares que dificilmente alcançariam através do crescimento orgânico num horizonte equiparável.

Gráfico 1 - Evolução da receita líquida das empresas selecionadas (R\$ milhões).

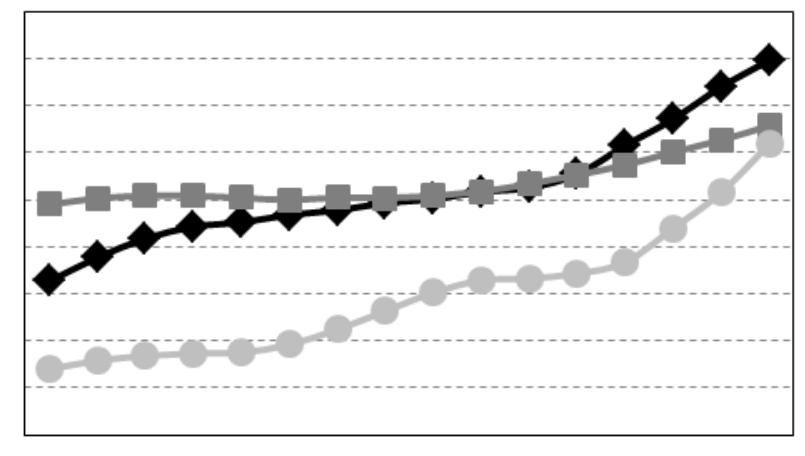

$\multimap$ Anhanguera $\rightarrow$ Estácio $\multimap$ Kroton

Fonte: autoria própria, com base em dados de Thomson, 2012

Nota: 0 valor indicado em cada período se refere à soma da receita líquida dos doze meses anteriores

O gráfico acima permite ver com clareza a forte tendência de crescimento das empresas estudadas ao longo dos últimos quatro anos, especialmente nos casos da Anhanguera e da Kroton, que realizaram aquisições de maior porte no período. É possível perceber, por exemplo, que a curva de receita líquida da Kroton é impactada em ocasiões pontuais pela integração das aquisições mais relevantes que realizou: IUNI no primeiro trimestre de 2012 (1T10), UNOPAR em 1 T12 e Uniasselvi em 3T12. 0 mesmo efeito se observa na curva da Anhanguera, como o impacto da integração da UNIPLI em 1T11 e da UNIBAN em 1T12. No caso da Estácio, como suas aquisições foram sempre de um porte menor, o efeito isolado de uma aquisição já não é tão 


\section{SINERGIAS NAS FUSÕES E AQUISIÇÕES DO SETOR DE EDUCAÇÃO SUPERIOR NO BRASIL}

perceptível.

Entre 4T08 e 3T12, as taxas médias de crescimento anual da Anhanguera, Estácio e Kroton foram, respectivamente, $27 \%, 8 \%$ e $49 \%$. Ao se confrontar estas taxas com o porte e a frequencia de aquisições realizadas por cada empresa, apresentadas no capítulo 5, percebe-se que há uma correlação entre as duas variáveis. A maior agressividade na estratégia de crescimento aquisitivo da Anhanguera e da Kroton lhe permitiram superar a Estácio, então líder de mercado em 2007, ano em que as três abriram seus capitais. No caso da Kroton, que realizou as maiores aquisições do setor, esta estratégia lhe permitiu mais que quadruplicar sua receita num horizonte de quatro anos. Seria muito improvável uma taxa tão acelerada baseada meramente no crescimento orgânico.

\section{Percentual de despesas comerciais, gerais e administrativas sobre a receita líquida}

É esperado algum ganho sinérgico em relação às despesas comerciais, gerais e administrativas, pela sua natureza mais fixa que, portanto, estaria mais propícia a uma diluição devido ao efeito dos ganhos de escala. A principal exceção neste grupo, todavia, seriam as despesas relacionadas à provisão de devedores duvidosos, que são um componente significativo dentro das despesas totais.

Gráfico 2 - Evolução do percentual de despesas comerciais, gerais e administrativas sobre a receita líquida.
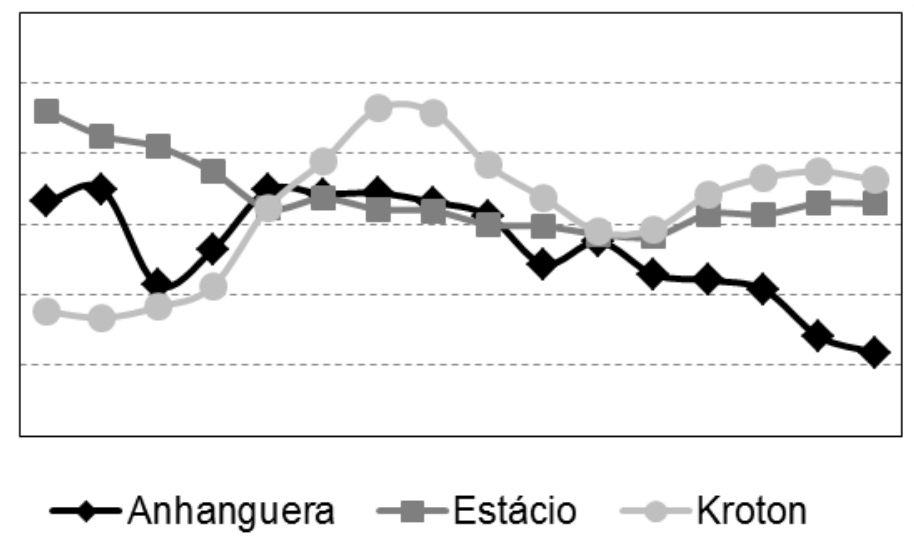

Fonte: autoria própria, com base em dados de Thomson, 2012 e Kroton, 2010a.

Nota: Segundo a Kroton (2010b), a empresa alterou seus critérios de provisionamento em 4T09, elevando consideravelmente a provisão com devedores duvidosos. Em 4T09 foi dada uma baixa de contas a receber e cheques devolvidos de $\mathrm{R} \$ 28,8$ milhões, conforme Kroton (2010a), que, por ter um caráter não-recorrente e para seguir o princípio da competência, foi excluída do cálculo deste e dos próximos indicadores.

0 gráfico acima revela que de fato é observada uma tendência de queda nos indicadores da Anhanguera e da Estácio, que em 3T12 apresentaram proporções de despesas comerciais, gerais e administrativas sobre a receita líquida 11 e 7 pontos percentuais inferiores às de 4T08, respectivamente. No caso da Anhanguera, pode-se dizer que há indícios que a aceleração da queda em 2012 possa estar relacionada à aquisição mais importante até hoje já realizada pela empresa, que foi a UNIBAN ao final de 2011. 
A curva do indicador da Kroton, por sua vez, apresenta um comportamento bastante singular. Como apresentado na nota explicativa do gráfico, a empresa alterou o seu critério de provisão de devedores duvidosos em 4T09, aplicado também à IUNI, que estava sendo adquirida no período, o que justificou a mudança de patamar do indicador nos trimestres subsequentes. Porém, após a normalização com o novo critério, seguiu-se uma queda no percentual analisado, que poderia, entre outros fatores, estar relacionada aos ganhos realizados com a integração da IUNI. Contudo, a tendência voltou a se inverter ao final de 2011 e, novamente, no último período analisado, 3T12, o que impede conclusões assertivas sobre como um potencial ganho sinérgico estaria afetando tal indicador.

\section{Margem operacional}

A evolução da margem operacional, que se trata do percentual do lucro operacional (receita líquida deduzida dos custos dos serviços prestados, despesas comerciais, gerais e administrativas e outras despesas e receitas operacionais), é uma consequência direta da evolução dos dois últimos indicadores.

\section{Gráfico 3 - Evolução da margem operacional.}
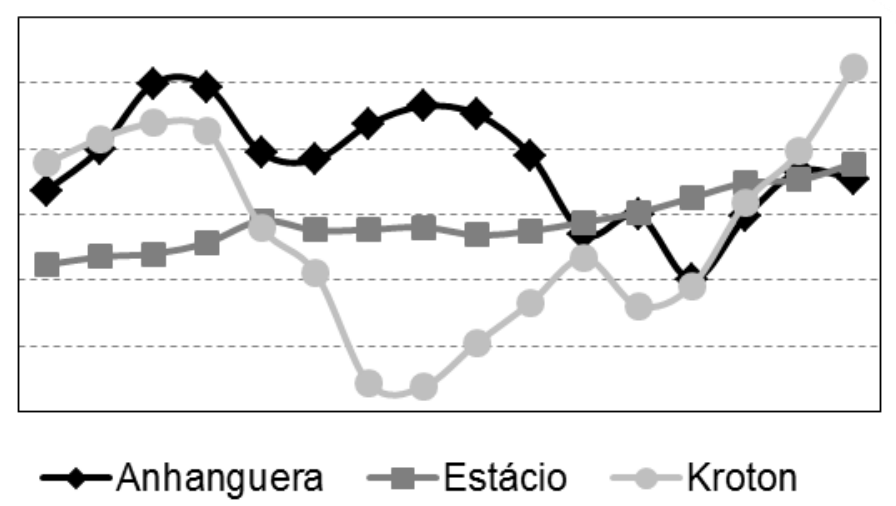

Fonte: autoria própria, com base em dados de Thomson, 2012 e Kroton, 2010a.

À primeira vista, é possível notar que as três empresas apresentaram em 3T12 margens operacionais superior àquelas apresentadas no primeiro período da série histórica analisada, 4T08. Contudo, a evolução da margem operacional de cada empresa apresentou comportamentos bastante distintos ao longo do tempo.

A Kroton, que em 4T08 possuía a maior margem, apresentou uma drástica queda a partir de 4T09, período que coincide com a aquisição da IUNI, a maior realizada pela empresa até então, bem como com a mudança da política de provisionamento que, conforme já explicado, afetou negativamente a rentabilidade da Kroton. Porém, após alguns períodos de prejuízo operacional, a partir de 4T10 a margem operacional da empresa cresceu de maneira vertiginosa e, empurrada pela queda no percentual de custos dos serviços prestados sobre a receita líquida, já mostrada, a Kroton recuperou a posição de melhor margem operacional entre suas concorrentes comparáveis.

No caso da Anhnaguera, vê-se também um comportamento irregular, mas inverso. Após apresentar um aumento na margem operacional a partir de 4T08, o indicador veio gradualmente caindo até $4 \mathrm{~T} 11$, quando se aproximou de zero. Neste período, todavia, a Anhanguera adquiriu a UNIBAN e, a partir de então, verificou-se uma forte queda no percentual de despesas comerciais, gerais e administrativas sobre a receita líquida, apresentada 


\section{SINERGIAS NAS FUSÕES E AQUISIÇÕES DO SETOR DE EDUCAÇÃO SUPERIOR NO BRASIL}

anteriormente, o que permitiu uma recuperação da margem operacional para um nível superior ao verificado no início da série histórica analisada.

Finalmente, a Estácio foi a empresa que apresentou uma evolução de margem operacional com comportamento mais regular: um crescimento gradual ao longo do tempo. Das três empresas, é válido ressaltar que a Estácio foi a única que optou por fazer sempre aquisições de menor porte que, portanto, não teriam impacto pontual tão significativo sobre os números da empresa. Desta forma, é nela que é mais fácil de se observar um ganho contínuo de rentabilidade operacional.

\section{Retorno sobre o patrimônio líquido}

O último indicador econômico-financeiro utilizado para a análise da realização de sinergias operacionais é o retorno sobre o patrimônio líquido, uma métrica que busca mensurar o retorno proporcionado pelas empresas aos seus acionistas. Ela é calculada dividindo-se o lucro líquido pelo valor contábil do patrimônio líquido. A princípio, seria esperado que caso de fato existissem potenciais sinergias operacionais nas aquisições realizadas pelas três empresas estudadas, que estas sinergias se convertessem numa maior rentabilidade e, consequentemente, num maior retorno sobre o patrimônio líquido, ceteris paribus.

Gráfico 4 - Evolução da do retorno sobre o patrimônio líquido.

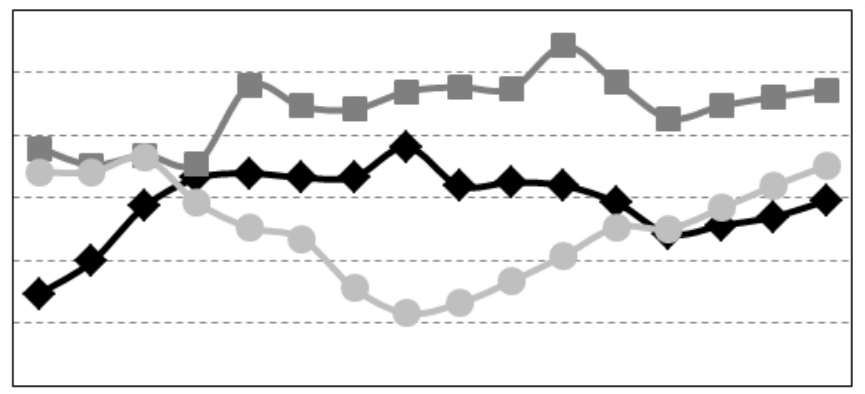

$\rightarrow$ Anhanguera $\rightarrow$ Estácio $\rightarrow$ Kroton

Fonte: autoria própria, com base em dados de Thomson, 2012 e Kroton, 2010a.

Mais uma vez, comparando os primeiros e os últimos pontos de cada uma das séries, é possível observar uma melhora no indicador nos três casos, ainda que com diferentes comportamentos. Adicionalmente, também na comparação entre 4T08 e 3T12, as posições relativas entre as empresas se mantiveram, com a Estácio apresentando o maior retorno sobre o patrimônio líquido e a Anhanguera o menor.

A começar pela Anhanguera, a empresa apresentou um expressivo crescimento do indicador ao longo de 2009, deixando de ser negativo. 0 patamar médio foi mantido até o início de 2011, quando começou a cair. É válido ressaltar, todavia, que segundo a Anhanguera (2010), ao final de 2010 a empresa fez mais uma distribuição primária de ações, o que elevou consideravelmente o denominador da métrica analisada, podendo justificar, ao menos parcialmente, sua queda num primeiro momento. 0 que se observou, entretanto, é que a partir de 4T11 o retorno sobre o patrimônio líquido da empresa retomou a tendência de crescimento, já estando próximo à média observada no período anterior de maior estabilidade. 
A Kroton, por sua vez, iniciou a série histórica apresentando um retorno sobre o patrimônio líquido de 7\%, mas logo viu este número despencar, chegando a valores negativos. Isto parece estar intimamente conectado à queda da margem operacional da empresa, pelos motivos já explicados anteriormente. No entanto, a partir do momento que os indicadores operacionais da Kroton passaram a apresentar uma tendência positiva, o retorno sobre o patrimônio líquido entrou numa tendência de crescimento. 0 indicador subiu de maneira gradual e incessante no ano de 2012, em que aquisições importantes como a da UNOPAR e da Uniasselvi foram realizadas, voltando a um patamar médio próximo ao observado antes da queda.

Já a Estácio mais uma vez foi a empresa que mostrou um comportamento mais regular em seus indicadores. Ainda que tenha havido quedas pontuais do retorno sobre o patrimônio líquido, a empresa apresentou uma clara tendência de crescimento gradual do indicador, o que pode ser considerada uma consequência natural do seu praticamente constante ganho de margem operacional. E, assim como suas duas principais concorrentes, o seu retorno sobre o patrimônio líquido tem crescido de maneira ininterrupta desde 4T11.

\section{Conclusões}

Primeiramente, foi possível identificar fontes específicas de potenciais sinergias no setor estudado a partir do aprofundamento do conhecimento sobre os principais direcionadores de rentabilidade e valor das empresas de educação superior privadas brasileiras. A partir desta identificação, também foi possível discutir a probabilidade de que cada potencial sinergia impactaria de maneira relevante os resultados das empresas, podendo-se assim focar naquelas mais prováveis de surtirem efeitos materiais.

Em seguida, após evidenciar a existência de potenciais sinergias, a análise dos indicadores econômico-financeiros das três empresas selecionadas também gerou indícios de que a adoção da estratégia de crescimento aquisitivo por parte delas estaria se traduzindo numa maior rentabilidade operacional, o que, ceteris paribus, vem a se converter em geração de valor econômico aos seus acionistas, assumindo-se a premissa de que os prêmios pagos às empresas adquiridas respeitariam o princípio de não serem superiores ao valor das sinergias.

Como demonstra a análise dos indicadores, foi verificada uma tendência de forte aumento de receita, que contém, entre outros, um elemento sinérgico operacional. Além disso, os indicadores também apontaram uma queda na proporção de custos e despesas em relação à receita líquida.

A Anhanguera optou primordialmente pela realização de diversas aquisições de médio porte, com foco no ensino presencial, capazes de fortalecer sua presença nos estados mais desenvolvidos da federação, totalmente concentrada no centro-sul do Brasil. Percebe-se também que o crescimento se deu particularmente no seu berço, o estado de São Paulo, e que a instituição se manteve distante da intenção de aumentar sua penetração significativamente no estado do Rio de Janeiro, tradicionalmente uma praça dominada pela sua concorrente Estácio, com apenas uma aquisição importante feita lá, a da UNIPLI.

A última transação relevante da Anhanguera, contudo, pode mostrar uma mudança no tamanho do seu apetite. A aquisição da UNIBAN ao final de 2011, a maior realizada pela empresa até então, pode sinalizar um interesse sobre instituições de maior porte, assim como a sua intenção de não perder a liderança no setor em número de alunos, que agora está claramente ameaçada pela voracidade aquisitiva da Kroton.

No caso da Kroton, há uma clara intenção de ganho rápido de escala, que pode ser depreendida 


\section{SINERGIAS NAS FUSÕES E AQUISIÇÕES DO SETOR DE EDUCAÇÃO SUPERIOR NO BRASIL}

das aquisições de instituições de grande porte, como a IUNI, UNOPAR e Uniasselvi, que colocaram a Kroton num patamar cerca de quatro vezes maior ao que apresentava na época da sua abertura de capital. Também é possível observar que outros direcionadores das aquisições foram a expansão geográfica e a diversificação da base de alunos, com foco em instituições de ensino à distância.

Novamente, assim como a Anhanguera, seus indicadores de rentabilidade apresentaram um comportamento irregular ao longo da série analisada, ainda que com uma tendência de melhora nos períodos mais recentes. É válido destacar que tais indicadores foram, em parte, prejudicados em 4T09 por uma mudança nas políticas contábeis da empresa, o que gera uma distorção na comparação período a período, mas que, a partir da completa adoção dos novos critérios, os indicadores da Kroton, em geral, evoluíram de maneira positiva.

A Estácio, por sua vez, foi a que mostrou uma tendência mais regular entre as comparáveis. Talvez seja possível afirmar que a empresa não primou pela quantidade, isto é, pela taxa de crescimento da receita, mas sim pela qualidade, ou seja, pela sustentação de indicadores positivos e progressivos.

Das três empresas, a Estácio foi a que fez menos aquisições no horizonte analisado, assim como foi a única que não fez uma aquisição de grande porte. As aquisições da Estácio foram principalmente de instituições de até cinco mil alunos e de até $\mathrm{R} \$ 25$ milhões de valor de empresa. Percebe-se também que o foco inicial, sobre instituições no estado de São Paulo, se converteu para regiões menos exploradas do norte e do nordeste do país. Adicionalmente, a empresa concentrou-se no ensino presencial, não tendo feito nenhuma aquisição de instituições de ensino à distância.

A maior regularidade demonstrada pela Estácio, ainda que tenha lhe feito perder a liderança nacional em receita e número de alunos, lhe proporcionou uma melhoria gradual e sustentável da rentabilidade e lhe deu uma grande vantagem em termos de retorno sobre o patrimônio líquido em relação às suas principais concorrentes.

Enfim, ainda que cada uma das empresas estudadas tenha suas singularidades, o presente trabalho conclui que a estratégia de crescimento aquisitivo adotada por estas empresas têm embasamento econômico. Existem evidências concretas de que existem fontes de ganhos sinérgicos, que, por sua vez, estão se traduzindo em melhores resultados econômicos. Portanto, caso as condições de atratividade de fusões e aquisições no setor se mantenham, é razoável admitir e projetar que continuarão ocorrendo transações na educação superior privada brasileira.

Acredita-se que o teste da primeira da hipótese levantada, isto é, a identificação da existência de sinergias específicas no setor estudado, apesar de comprovado por meios qualitativos, poderia ter sido ainda mais acentuado caso todas as empresas abordadas tivessem contribuído com as respostas ao questionário enviado. Tentou-se insistentemente conseguir tais contribuições por parte da Anhanguera e um aprofundamento do que foi enviado pela Kroton, mas não foi possível, mesmo feitas todas as ressalvas que garantiam a tais empresas a não divulgação de informações que pudessem ser consideradas sensíveis ou confidenciais. 


\section{Referências}

AMARAL, A.; MAGALHÃES, A. O conceito de stakeholder e o novo paradigma do ensino superior. Revista Portuguesa de Educação, Braga, v. 13, n. 2, p. 7-28, 2000.

AMIT, R.; LIVNAT, J.; ZAROWIN, P. A classification of mergers and acquisitions by motives: analysis of market responses. Contemporary Accounting Research. Estados Unidos, v. 6, n.1, p. 143-158, set./dez. 1989.

AMORIM, L. Na Kroton, o minoritário virou chefe. Exame. 4 mai. 2011. Disponível em: <http://exame.abril.com.br/revista-exame/edicoes/0991/noticias/o-minoritario-virou-chefe>. Acesso em: 15 nov. 2012.

ANHANGUERA. Prospecto definitivo de distribuição pública primária e secundária de certificados de depósito de ações ("units") de emissão da Anhanguera Educacional. São Paulo: Anhanguera Educacional, 2007.

ANHANGUERA. Prospecto definitivo de oferta pública de distribuição primária de ações ordinárias de emissão da Anhanguera Educacional. São Paulo: Anhanguera Educacional, 2010.

ANHANGUERA. Resultado 3T12. Valinhos: Anhanguera Educional, 2012a. Disponível em: <http://www.mzweb.com.br/anhanguera2011/web/download_arquivos.asp?id_arquivo=E9EE E523-23E9-48C9-959A-3DED5E8FA038>. Acesso em: 10 nov. 2012.

APSIS. Laudo de avaliação: RJ-0043/11-02 - Estácio Participações. 2011. Disponível em: <http://www.estacioparticipacoes.com/estacio2010/web/arquivos/Estacio_Laudo_20110317_ port.pdf>. Acesso em: 29 set. 2012.

BALL, S. J. Education for sale! The commodification of everything? Londres: University of London, 2004.

BANCO J. SAFRA. Prospects are positive and prices attractive: we favor KROT11 and ABRE11. Sector Note: Education, São Paulo, ago. 2012.

BERKOVITCH, E.; NARAYANAN, M. P. Motives for takeovers: an empirical investigation. Journal of Financial \& Quantitative Analysis, Seattle, v. 28, n.3, p. 347-362, set. 1993.

BRASIL. Constituição da República Federativa do Brasil de 1988. Brasília, 1988.

BRASIL. Lei no 11.096/2005. Brasília, 2005.

BRIGHAM, E. F.; EHRHARDT, M. C. Financial management: theory and practice. Estados Unidos: Thomson South-Western, 2005.

CAIXA ECONÔMICA FEDERAL. FIES - Financiamento Estudantil. Brasília, 2012. Disponível em: <http://www3.caixa.gov.br/fies/FIES_FinancEstudantil.asp>. Acesso em: 4 nov. 2012.

CAMARGOS, M. A.; BARBOSA, F. V. Fusões, aquisições e takeovers: um levantamento teórico dos motivos, hipóteses testáveis e evidências empíricas. Caderno de Pesquisas em Administração, São Paulo, v. 10, n. 2, p.17-38, abr./jun. 2003.

CAMARGOS, M. A.; BARBOSA, F. V. Análise do desempenho econômico-financeiro e da criação de sinergias em processos de fusões e aquisições do mercado brasileiro ocorridos entre 1995 e 1999. Caderno de Pesquisas em Administração, São Paulo, v. 12, n. 2, p. 99-115, abr./jun. 


\section{SINERGIAS NAS FUSÕES E AQUISIÇÕES DO SETOR DE EDUCAÇÃO SUPERIOR NO BRASIL}

\section{5}

CAMARGOS, M. A.; BARBOSA, F. V. Fusões e aquisições de empresas brasileiras: criação de valor e sinergias operacionais. Revista de Administração de Empresas, São Paulo, v. 49, n. 2, abr./jun. 2009.

CARVALHO, C. H. A. Política para o ensino superior no Brasil (1995-2006): ruptura e continuidade nas relações entre público e privado. Campinas: Universidade de Campinas (UNICAMP), 2006.

CELLINI, S. R. For-profit higher education: an assessment of costs and benefits. National Tax Journal, Washington, v.6, n.1, p. 153-180, mar. 2012.

CHATTERJEE, S. Types of synergy and economic value: the impact of acquisitions on merging and rival firms. Strategic Management Journal, Estados Unidos, v. 7, p. 119-139, 1986.

CHOPRA, S.; MEINDL, P. Gerenciamento da cadeia de suprimentos: estratégia, planejamento e operação. São Paulo: Prentice Hall, 2003.

CIEGLINSKI, A. MEC muda critério para que instituições recebam isenção por bolsas do ProUni. Agência Brasil. 2 jun. 2011. Disponível em: <http://agenciabrasil.ebc.com.br/noticia/2011-0602/mec-muda-criteri

o-para-que-instituicoes-recebam-isencao-por-bolsas-do-prouni>. Acesso em: 4 nov. 2012.

DEUTSCHE BANK. Homework assignment: buy ESTC3, AEDU3 and KROT11. Markets Research: Education, São Paulo, jan. 2012.

DEVOS E.; KADAPAKKAM, P. R.; KRISHNAMURTHY, S. How do mergers create value? A comparison of taxes, market power, and efficiency improvements as explanations for synergies. The Review of Financial Studies, Oxford, v. 22, n. 3, 2009.

DOMInGUES, M. A. I. Publicação eletrônica: estudo para o mestrado da Fundação Getulio Vargas [mensagem pessoal]. Mensagem recebida por <alands@gmail.com> em 8 nov. 2012.

DURHAM, E. R. Educação superior, pública e privada. In: SCHWARTZMAN, S.; BROCK, C. Os desafios para a educação no Brasil. Rio de Janeiro: Nova Fronteira, 2005.

ESTÁCIO. Prospecto definitivo de oferta pública de distribuição primária e secundária de units de emissão da Estácio Participações. São Paulo: Estácio Participações, 2007.

ESTÁCIO. Resultados do 2T12. Rio de Janeiro: Estácio Participações, 2012a. Disponível em: $<$ http://www.estacioparticipacoes.com/estacio

2010/web/arquivos/Estacio_APRCall_2T12_port.pdf>. Acesso em: 29 set. 2012.

ESTÁCIO. Resultados do 3T12. Rio de Janeiro: Estácio Participações, 2012b. Disponível em: <http://www.estacioparticipacoes.com.br/estacio2010/web/download_arquivos.asp?id_arquiv o=18FF9842-DC5A-4E05-9D1A-B60CEF7ABD6C>. Acesso em: 10 nov. 2012.

ESTÁCIO. História. Estácio Participações, 2012c. Disponível em: <http://portal.estacio.br/quem-somos/historia.aspx>. Acesso em: 11 nov. 2012. 
FLUGT, C. Shareholder wealth effects of mergers and acquisitions: an empirical investigation of short-term performance in the European market. Dinamarca: Universidade de Aarhus, 2009.

FRIED, V. H.; HILL, A. D. The future of for-profit higher education. The Journal of Private Equity, Nova Iorque, out./dez. 2009.

IBGE. PNAD 2011: crescimento da renda foi maior nas classes de rendimento mais baixas. Brasília: Instituto Brasileiro de Geografia e Estatística, 2012. Disponível em: <http://www.ibge.gov.br/home/presidencia/noticias/noticia_visualiza.php?id_noticia=2222\&i d_pagina=1>. Acesso em: 2 nov. 2012.

INEP. Censo da educação superior 2010: resumo técnico. Brasília: Instituto Nacional de Estudos e Pesquisas Educacionais Anísio Teixeira, 2012.

KLUYVER, C. A.; PEARCE II, J. A. Estratégia: uma visão executiva. São Paulo: Prentice Hall, 2007.

KODE, G. V. M.; FORD, J. C.; SUTHERLAND, M. M. A conceptual model for evaluation of synergies in mergers and acquisitions: a critical review of the literature. South African Journal of Business Management, Joanesburgo, v. 34, 2003.

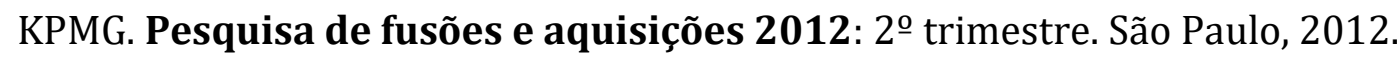

KRISHNAM, H. A.; KRISHNAM, R.; LEFANOWICZ, C. E. Market perception of synergies in related acquisitions. Academy of Strategic Management Journal, Estados Unidos, v. 8, p. 99-119, jan. 2009.

KROTON. Prospecto definitivo de distribuição pública primária e secundária de certificados de depósito de ações ("units") de emissão da Kroton Educacional. São Paulo: Kroton Educacional, 2007.

KROTON. Divulgação dos resultados 2009. São Paulo: Kroton Educacional, 2010a. Disponível em: <http://ri.kroton.com.br/kroton2010/web/arquivos/Kroton_ER_4Q09_pt.pdf>. Acesso em: 15 nov. 2012.

KROTON. Divulgação dos resultados 1T10. São Paulo: Kroton Educacional, 2010b. Disponível em: <http://ri.kroton.com.br/kroton2010/web/arquivos/kroton_resultado_1t10_pt.pdf>. Acesso em: 15 nov. 2012.

KROTON. Unopar. São Paulo: Kroton Educacional, 2011. Disponível em: <http://ri.kroton.com.br/kroton2010/web/arquivos/unopar\%20presentation\%20analistas\%2 0port\%20call.pdf>. Acesso em: 29 set. 2012.

KROTON. Apresentação de resultados 3T12. São Paulo: Kroton Educacional, 2012a. Disponível em: <http://ri.kroton.com.br/kroton2010/ web/download_arquivos.asp?id_arquivo=23A6730D-C977-4BAD-85CC-C57FAB19A867>. Acesso em: 10 nov. 2012.

KROTON. Histórico. Kroton Educional, 2012b. Disponível em: <http://www.mzweb.com.br/kroton2010/web/conteudo_pti.asp?idioma=0\&conta=45\&tipo=3 4091>. Acesso em: 11 nov. 2012.

KROTON. Comunicado ao mercado: Kroton adquire Grupo Uniasselvi. Kroton Educacional, 2012c.

Disponível em: $<$ http://www.mzweb. 


\section{SINERGIAS NAS FUSÕES E AQUISIÇÕES DO SETOR DE EDUCAÇÃO SUPERIOR NO BRASIL}

com.br/kroton2010/web/conteudo_pti.asp?idioma=0\&tipo $=34100 \&$ conta $=45 \& \mathrm{id}=155017>$. Acesso em: 11 nov. 2011.

KROTON. Institutional presentation. São Paulo: Kroton Educacional, 2012d.

LEVIDOW, L. Marketizing higher education: neoliberal strategies and counter-strategies. The Commoner, Reino Unido, n. 3, jan. 2002.

LOCKETT, A.; WIKLUND, J.; DAVIDSSON, P.; GIRMA, S. Organic and acquisitive growth: reexamining, testing and extending Penrose's growth theory. Journal of Management Studies, Oxford, v48, n.1, jan. 2011.

MACEDO, A. R.; TREVISAN, L. M. V.; TREVISAN, P.; MACEDO, C. S. Educação superior no século XXI e a reforma universitária brasileira. Ensaio: Avaliação e Políticas Públicas em Educação, Rio de Janeiro, v. 13, n. 47, p. 127-148, abr./jun. 2005.

MARGINSON, S. Competition and Markets in Higher Education: a 'glonacal' analysis. Policy Futures in Education, Oxford, v. 2, n. 2, 2004.

MARTELANC, R., PASIN, R.; PEREIRA, F. Avaliação de empresas: um guia para fusões \& aquisições e private equity. São Paulo: Prentice Hall, 2010.

MATIAS, A. B.; BARRETTO, A. C. P. M.; GORGATI, V. Fusões e aquisições no Brasil atual: possibilidades de ocorrência de uma onda. São Paulo: Universidade de São Paulo, 1996.

MATIAS, A. B; PASIN, R. M. A geração de sinergias e seus impactos na rentabilidade das empresas nos casos de fusões e aquisições. Revista de Administração, São Paulo, v. 36, n. 1, p. 5-13, jan./mar. 2001.

MÁXIMO, L. Com Prouni, faculdades particulares deixarão de pagar R\$ 1 bi em impostos. Valor Econômico. 9 mai. 2012. Disponível em: <http://www.valor.com.br/brasil/2650876/comprouni-faculdades-particulares-deixarao-de-pagar-r-1-bi-em-impostos $>$. Acesso em: 2 nov. 2012.

MEEKS, G. Disappointing marriage: a study of the gains from merger. Cambridge: Cambridge University Press, 1977.

MINISTÉRIO DA FAZENDA. Perspectivas da economia em 2012 e medidas do governo. Brasília, 2012.

NINNI, K., CRUZ, R. Anhanguera compra Uniban por R\$ 510 milhões. 0 Estado de São Paulo. 20 set. 2011. Disponível em <http://www.estadao.com.br/noticias/vidae,anhanguera-comprauniban-por-r-510-milhoes,774783,0.htm>. Acesso em: 27 out. 2012.

NYBERG, A. J.; FULMER, I. S.; GERHART, B.; CARPENTER, M. A. Agency theory revisited: CEO return and shareholder interest alignment. Academy of Management Journal, Briarcliff Manor, v. 53, issue 5, p. 1029-1049, 2010.

OECD. Education at a glance 2011: highlights. Paris: OECD Publishing, 2011.

OLIVEIRA, O. V.; FORTE, S. H. A. C.; ARAGÃO, L. A. Fusões e aquisições sob a perspectiva da 
vantagem competitiva: o caso da Perdigão Agroindustrial S.A. Revista Brasileira de Gestão de Negócios, São Paulo v. 9, n. 24, p. 91-108., mai./ago. 2007.

OTRANTO, C. R. Desvendando a política da educação superior do governo Lula. Revista Universidade e Sociedade - ANDES-SN, Brasília, ano XVI, n. 38, p. 18-29, jun. 2006.

OXFORD DICTIONARIES. Definition of synergy. Oxford, 2012. Disponível em: <http://oxforddictionaries.com/definition/english/synergy>. Acesso em: 14 out. 2012.

PENROSE, E. T. The theory of growth of the firm. Oxford: Oxford University Press, 1995.

PINDYCK, R. S.; RUBINFELD D. L. Microeconomia. São Paulo: Prentice Hall, 2005.

SÉCCA, R. X.; LEAL, R. M. Análise do setor de ensino superior privado no Brasil. BNDES Setorial, Rio de Janeiro, n. 30, set. 2009.

SETH, A.; SONG, K. P.; PETTIT, R.. Synergy, managerialism or hubris? An empirical examination of motives for foreign acquisitions of U.S. firms. Journal of International Business Studies, Estados Unidos, v. 31, n.3, p. 387-405, jul./set. 2000.

SGUISSARDI, V. Modelo de expansão da educação superior no Brasil: predomínio privado/mercantil e desafios para a regulação e a formação universitária. Educação \& Sociedade, Campinas, v. 29, n. 105, p. 991-1022, set./dez. 2008.

SILVA, E. A. A. Direito à educação e educação para todos numa sociedade em desenvolvimento o caso de Angola. In: VII Congresso Luso-Afro-Brasileiro de Ciências Sociais. Coimbra: Centro de Estudos Sociais, Faculdade de Economia, Universidade de Coimbra, 2004.

SILVA JR., J. R.; SGUISSARDI, V. A nova lei de educação superior: fortalecimento do setor público e regulação do privado/mercantil ou continuidade da privatização e mercantilização do público? Revista Brasileira de Educação, Rio de Janeiro, n. 29, mai./ago. 2005.

SISTEMA PROUNI. Bolsas ofertadas por ano. Brasília, 2012. Disponível em: <http://siteprouni.mec.gov.br/images/arquivos/pdf/Representacoes_graficas/bolsas_ofertadas _ano.pdf>. Acesso em: 4 nov. 2012.

SUDARSANAM, P. S. The essence of mergers and acquisitions. Londres: Prentice Hall, 1995.

THOMSON. Worldscope fundamentals. Thomson One Analytics, 2012. Disponível em: <https://www.thomsononeim.com/v-hom.asp\#>. Acesso em: 17 nov. 2012.

WESTON, J. F.; CHUNG, K. S.; HOAG, S. E. Mergers, restructuring, and corporate control. Englewood Cliffs: Prentice Hall, 1990.

WOOD JR., T.; VASCONCELOS, F. C.; CALDAS, M. P. Fusões e aquisições no Brasil. Revista de Administração de Empresas - RAE Executivo, São Paulo, v. 2, n. 4. nov. 2003 / jan. 2004. 